\title{
KRYZYS GOCKI Z PERSPEKTYWY HISTORIOGRAFII KOŚCIELNEJ V STULECIA
}

\section{Sławomir Bralewski}

http://orcid.org/0000-0002-4708-0103

\author{
Uniwersytet Łódzki
}

\section{ABSTRACT \\ THE GOTHIC CRISIS FROM THE PERSPECTIVE OF ECCLESIASTICAL HISTORIOGRAPHY OF THE $5^{\text {TH }}$ CENTURY}

In the second half of the $4^{\text {th }}$ century, the migration of Goths to the Balkan Peninsula took place, which led to a serious crisis in the Roman Empire. Its consequence was the defeat suffered by the Romans at Adrianople (378), in which emperor Valens died. This battle is considered to be one of the decisive battles in the history of mankind, which has changed the face of the late Roman history to such an extent that one sees it as a caesura marking the end of antiquity. How did the authors of ecclesiastical histories living at that time as those who, after all, devoted a lot of space to political history in their works relate to these events and to the entire Gothic crisis that was the result of the migration of the Goths? Is it possible to see any differences in the presentation of these events by Rufin of Aquileia, Socrates of Constantinople, Sozomen, Philostorgius or Theodoret of Cyrus? The author tries to answer these questions in this article.

Keywords: Late Roman Empire, Goths, battle of Adrianople, emperor Valens, ecclesiastical historiography.

Słowa kluczowe: późne cesarstwo rzymskie, Goci, bitwa pod Adrianopolem, cesarz Walens, historiografia kościelna.

Już Ambroży, biskup Mediolanu, dostrzegł ciąg wydarzeń, które zapoczątkowały wielką wędrówkę ludów. Jak pisał: „Hunowie skierowali się przeciw Alanom, Alanowie przeciw Gotom, Gotowie przeciw Tajfalom i Sarmatom"1. W konsekwencji

${ }^{1}$ A mbrosius, Expositio Evangelii secundum Lucam, X, 10, ed. M. Adria en, Turnhout 1957. Na temat „Beginn der Völkerwanderung” zob. G. Halsall, Barbarian Migrations and the Roman West, 376-568, Cambridge 2007, s. 170-175; M. Meier, Geschichte der Völkerwanderung: Europa, Asien und Afrika vom 3. bis zum 8. Jahrhundert n.Chr., München 2020, s. 125-223.

Adres do korespondencji: slawomir.bralewski@filhist.uni.lodz.pl 
wspomnianych zawirowań doszło do przemieszczenia się plemion i naporu Gotów na rzymskie terytorium ${ }^{2}$. Dwa wydarzenia związane z migracją Gotów wstrząsnęły cesarstwem rzymskim na przełomie IV i V wieku: były to klęska pod Adrianopolem w roku 378 i zdobycie Rzymu w roku 410. Pierwsze z nich uchodzi nawet za jedną z decydujących bitew w dziejach ludzkości, która zmieniła oblicze dziejów późnorzymskich do tego stopnia, że widzi się w niej cezurę wyznaczającą koniec starożytności ${ }^{3}$. Drugie natomiast wydawało się przeczyć ugruntowanemu w świadomości samych Rzymian przekonaniu o urbs aeterna $a^{4}$, ale też zdawało się bardzo poważnym zagrożeniem dla ortodoksji w Kościele. Obawy te wyraził Rufin z Akwilei w prologu do przetłumaczonej przez siebie na łacinę Historii kościelnej Euzebiusza z Cezarei, kiedy pisał o przełamaniu zapory w Italii przez Alaryka, wodza Gotów, co umożliwiło szerzenie się niszczącej choroby (morbus) czy śmiertelnego grzechu (commissis feralis) - autor miał prawdopodobnie na myśli wyznawany przez Gotów arianizm5 ${ }^{5}$. W niniejszym artykule odniosę się do pierwszego ze wspomnianych wydarzeń. Zbadam, w jaki sposób do kryzysu gockiego wywołanego przez migrację Gotów, którego kulminacją była bitwa pod Adrianopolem, odnieśli się piszący w pierwszej połowie

${ }^{2}$ Oczywiście relacje Rzymian z Gotami sięgają czasów znacznie wcześniejszych. Rzymskie imperium już w III w. zmagało się z łupieżczymi wyprawami Gotów. Zob. G.M. B ernd t, Aktionsradien gotischer Kriegergruppen, „Frühmittelalterliche Studien” 2014, vol. 47, s. 10-24; M. Wilczyński, Wizygoci w rejonie Bałkanów w teorii i praktyce politycznej dworów późnego Cesarstwa Rzymskiego, „Vox Patrum” 2016, t. 66, nr 36, s. 302-303.

3 Timothy D. B arnes (The Collapse of the Homoeans in the East, „Studia Patristica” 1997, no. 29, s. 3) uznał starcie pod Adrianopolem za jedną z decydujących bitew w dziejach ludzkości. Marek Wilczyński (Germanie w stużbie zachodniorzymskiej w V w. n.e., Oświęcim 2018, s. 484, przyp. 6) wskazywał zaś na nieodwracalne skutki klęski pod Adrianopolem, zmieniające oblicze dziejów późnorzymskich do tego stopnia, że niektórzy badacze byli skłonni uznać dzień wspomnianej bitwy za koniec starożytności. Zob. też T.S. Burns, The Battle of Adrianople: A Reconsideration, „Historia” 1973, t. 22, nr 2, s. 336-345; B. Rutowski, Bitwa pod Adrianopolem (9 VIII 378 r.) i jej nastepstwa, „Meander" 1978, t. 33, nr 11-12, s. 525-539; N. Lenski, Initium mali Romano imperio: Contemporary Reactions to the Battle of Adrianople, „Transactions of the American Philological Association” 1997, no. 127, s. 129-168; S. Willi a m s, G. Friell, Theodosius the Empire at Bay, London 2005, s. 152-156; M.N. Pawlak, Cesarstwo rzymskie od Walentyniana I do Teodozjusza I (363-395) [w:] Świat rzymski w IV wieku, red. P. Filipc zak, R. Kosiński, Kraków 2015, s. 152-155.

${ }^{4}$ Literatura przedmiotu na ten temat jest niezwykle bogata. Zob. m.in. W.E. Kaegi, Byzantium and the Decline of Rome, Princeton 1968, passim; M. S a l a m o n, Rozpad i upadek cesarstwa rzymskiego. Społeczeństwo wobec nowych struktur politycznych [w:] Starożytny Rzym we wspótczesnych badaniach. Państwo - spoleczeństwo - gospodarka. Liber in memoriam Lodovici Piotrowicz, red. J. Wo $1 \mathrm{sk}$ i, T. Kotula, A. Kun is z, Kraków 1994, s. 197; H. Wolfra m, Historia Gotów, thum. R. Darda-S ta ab, I. Dę bek, K. B erger, Warszawa 2003, s. 186-189; P. He ather, Upadek cesarstwa rzymskiego, thum. J. Szczepański, Poznań 2006, s. 268-274.

${ }_{5}^{5}$ Prologus Rufini in Libros Historiarum Eusebii, s. 952. Jeśli Rufin lękał się, że obecność Gotów w Italii wpłynie na szerzenie się tam arianizmu, to jego obawy się nie sprawdziły. W pierwszej połowie V w. Wizygoci, w przeciwieństwie do Wandalów, nie próbowali nawracać Rzymian ani narzucać im swojego wyznania. W dodatku ich działalność w Italii doprowadziła do powstania niekorzystnego dla arian stereotypu i polaryzacji: Rzymianin - ortodoks, a barbarzyńca - arianin. W przekonaniu E. F a b e r a (Athanarich, Alarich, Athaulf. Zum Wandel westgotischer Herrschaftskonzeptionen, „Klio” 2010, Bd. 19, H. 1, s. 168): „Alarich etablierte ein Heerkönigtum und trug durch die Erfolge, zu denen er seine Gruppe führte, wesentlich zur Ethnogenese der Westgoten bei". 
V wieku autorzy historii kościelnych, poświęcający przecież niemało miejsca dziejom politycznym. Czy można dostrzec jakieś różnice w prezentowaniu wspomnianych wydarzeń przez Rufina z Akwilei, Sokratesa z Konstantynopola, Hermiasza Sozomena, Filostorgiusza czy Teodoreta z Cyru? Jest to ciekawe, tym bardziej że wywodzili się oni z różnych części Imperium Romanum. Pierwszy z nich pochodził z pars Occidentis, czterej pozostali z pars Orientis. Reprezentowali też różne środowiska: Sokrates, Sozomen i Filostorgiusz byli związani ze środowiskiem stołecznym, konstantynopolitańskim; Teodoret ze środowiskiem antiocheńskim, a Rufin, choć niemało czasu spędził na Wschodzie cesarstwa, reprezentował Kościół rzymski. Czy zatem odległość geograficzna rzutowała na sposób postrzegania migracji gockiej i wywołanego przez nią kryzysu? Na te pytania postaram się odpowiedzieć.

\section{PANOWANIE KONSTANTYNA}

Najwięcej informacji na temat Gotów ze wszystkich wymienionych autorów zawarli w swych Historiach kościelnych Sokrates i Sozomen, przy czym trudno pozbyć się wrażenia, że drugi z nich, piszący później, korygował relację swego poprzednika. Tym jednak, który pisał najwcześniej, był Rufin z Akwilei. Na jego zaś dziele pierwotną wersję swej Historii oparł Sokrates. Rufin o Gotach wspomniał już w odniesieniu do panowania Konstantyna Wielkiego, nadmieniając, że władca ów pobił Gotów na ich własnej ziemi ${ }^{6}$. Podobnie Sokrates z Konstantynopola o najazdach Gotów na cesarstwo pisał już w pierwszej księdze swej Historii kościelnej, którą poświęcił panowaniu Konstantyna $\mathrm{I}^{7}$. Po informacjach o zwycięstwie nad Licyniuszem, obradach soboru w Nicei, budowie Konstantynopola czy wyprawie Heleny, matki cesarza Konstantyna, do Ziemi Świętej wspomniał o najazdach Sarmatów i Gotów. Wedle jego relacji cesarz Konstantyn, pokładając ufność w znaku Chrystusa, nie tylko odniósł walne zwycięstwo nad barbarzyńcami, ale też uwolnił cesarstwo od kontrybucji, jaką poprzedni cesarze „zwyczajowo wypłacali barbarzyńcom”. Sokrates wskazywał na niespodziewaną klęskę barbarzyńców, co może sugerować, że w jego przekonaniu przewaga militarna leżała po ich stronie. Byli tak bardzo zadziwieni swoją porażką, że miała ich ona przekonać do siły Boskiego patrona Konstantyna, skoro - jak pisał Sokrates - wówczas ,„po raz pierwszy uwierzyli w moc religii chrześcijańskiej, która ochroniła [...] Konstantyna"». Po raz pierwszy zaufali potę-

${ }^{6}$ Rufinus Aquileiensis, Historia ecclesiastica, X, 8, ed. E. Schwartz, T. Mommsen, F. Winkelmann, Berlin 1999 [dalej: Rufinus]. Konstantyn Wielki toczył walki z Gotami przynajmniej trzykrotnie w latach 324, 332 i 336. Nomen pro virtute „Gothicus” władca ów przyjął prawdopodobnie dopiero pokonawszy Gotów na ich terenie po sforsowaniu Dunaju w 336 r.; zob. A. Demandt, Geschichte der Spätantike. Das Römische Reich von Diocletian bis Justinian 282-565 n. Chr., München 2008, s. 54; M. Wilczyńs ki, Wizygoci w rejonie Bałkanów..., s. 303.

7 Socrates, Historia ecclesiastica, I, 18, ed. G.Ch. Han s en, Berlin 1995 [dalej: S ocrates].

8 Socrates, I, 18.4; tłum. S. Kazikowski, Warszawa 1986, s. 113. 
dze Chrystusa za rządów Konstantyna, ale chrześcijaństwo mieli oficjalnie przyjąć dopiero za panowania cesarza Walensa (364-378), o czym informował Sokrates w partii swego dzieła poświęconej temu cesarzowi. Ciekawe, że Sozomen nieco inaczej odniósł się do relacji Gotów z cesarstwem rzymskim za panowania Konstantyna Wielkiego. Pisząc o szerzeniu się chrześcijaństwa w Imperium Romanum, wskazywał, że dotarło ono także do barbarzyńców i dawał za przykład między innymi Gotów. Podkreślał przy tym, że „Goci i wszyscy dawniejsi ich sąsiedzi znad brzegów

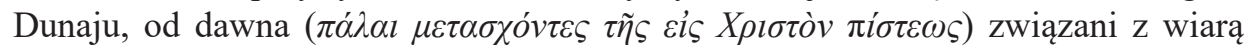
w Chrystusa, nagięli się do bardziej kulturalnego i rozsądnego trybu życia" ". Podobnie zresztą pisał Teodoret, wskazując, że Goci od dawna ( $\pi \alpha \dot{\lambda} \alpha \iota)$ przyjmowali światło Boskiej wiedzy $(\theta \varepsilon o \gamma v \omega \sigma i ́ \alpha \varsigma)$ i karmili się nauką apostołów ${ }^{10}$. W jaki sposób obydwaj autorzy rozumieli pojęcie „od dawna”? Wydaje się, że Sozomen chciał w ten sposób zasugerować, iż Goci wyprzedzili inne plemiona barbarzyńskie w przyjęciu chrześcijaństwa. Jeśli zaś chodzi o Teodoreta, to z kontekstu jego relacji wynika, iż chciał on zaznaczyć, że Goci schrystianizowali się wiele lat przed panowaniem Walensa.

\section{PANOWANIE WALENSA}

Goci kolejny raz pojawiają się w historiografii kościelnej za panowania cesarza Walensa. Rufin konstatował krótko, że za jego rządów wypędzeni ze swoich domostw Goci spustoszyli Trację ${ }^{11}$. Sokrates natomiast opisywał, jak to Walens wmieszał się w ich wewnętrzne rozgrywki o władzę ${ }^{12}$, udzielając wsparcia Fritigernowi przeciw Atanarykowi. Początkowo Fritigern, pokonany przez Atanaryka, szukał schronienia i wsparcia u Rzymian, a z pomocą rzymskich garnizonów trackich zdołał go pokonać.

9 Sozomenus, Historia ecclesiastica, II, 6,1, ed. J. Bidez, G.Ch. Han se n, Berlin 1995 [dalej: Sozomenus]. Goci od panowania Konstantyna Wielkiego bez przeszkód uczestniczyli w handlu prowadzonym na terenach naddunajskich; zob. G. Ka m pers, Geschichte der Westgoten, Paderborn 2008, s. 51 .

${ }^{10}$ Theodoretus, Kirchengeschichte [Historia ecclesiastica], IV, 37, ed. L. Parmentier, G.Ch. Han sen, Berlin-New York 2009 [dalej: The odoretus].

${ }^{11}$ Rufinus, XI, 13.

${ }^{12}$ Rozłam nastąpił wśród Wizygotów, zwanych też Terwingami. Sokrates pominął w swej relacji wojnę, którą cesarz Walens prowadził z Gotami w latach 367-369, rozpoczętą w związku z uzurpacją Prokopiusza. Na temat jej genezy i przebiegu zob. Ammianus Marcellinus, Rerum gestarum libri, XXVII, 5, 1-10, ed. É. Galletier, t. V, Paris 1984 [dalej: Ammianus Marcellinus], s. 16; Eunapios z Sardes, Zapiski historyczne. Istorika Upomnemata, wyd. i thum. A. Pająkowska- Bouallegui, Gdańsk 2013 [dalej: Eunapios], fr. 37, 78-79; Zosimos, Historia Nova, IV, 10, 1-3; 11, 1-4, ed. F. Pas choud, t. 2, Paris 1979 [dalej: Zosimos], s. 271-273 (Zarówno Eunapiusz, jak i Zosym nazywają Wizygotów Scytami). Zob. też U. Wan ke, Die Gotenkriege des Valens. Studien zu Topographie und Chronologie im unteren Donauraum von 366 bis 378 n. Chr., Europäische Hochschulschriften, Reihe III - Geschichte und ihre Hilfswissenschaften, Bd. 412, Frankfurt am Main 1990, passim; H. Wolfram, Historia Gotów, s. 85-88; M.N. Pawlak, Cesarstwo rzymskie..., s. 125-127. 
W dowód wdzięczności miał przyjąć religię cesarza i nakazał to samo swoim poddanym, w związku z czym wielu spośród barbarzyńców miało przyjąć chrześcijaństwo. W ten sposób Sokrates tłumaczył też, dlaczego Goci stali się wyznawcami doktryny ariańskiej, wskazując, że za nią opowiadał się Walens ${ }^{13}$. Z dawniejszych wywodów Sokratesa wynika jednak, że jakaś część Gotów przyjęła chrześcijaństwo już wcześniej, skoro mieli oni swojego biskupa. Historyk bowiem w księdze II swego dzieła wskazywał, że Wulfila, biskup Gotów, do roku 360, kiedy to opowiedział się za wyznaniem wiary przyjętym na synodzie w Konstantynopolu, trwał przy nicejskiej formule wiary, gdyż wzorował się na swoim poprzedniku Teofilu, uczestniku obrad w Nicei ${ }^{14}$. Z tego fragmentu wynika więc jasno, że Goci przyjęli chrześcijaństwo jeszcze przed soborem w Nicei, skoro w jego obradach uczestniczył biskup określany mianem biskupa Gotów. Podobnie ich alians $\mathrm{z}$ arianizmem miał miejsce jeszcze przed panowaniem Walensa, skoro, jak wskazywał Sokrates, już w 360 roku ich biskup podpisał się pod arianizującą formułą ${ }^{15}$. Kolejne informacje przytoczone przez Sokratesa na temat Gotów dotyczyły już ich migracji na rzymskie terytorium pod naciskiem Hunów ${ }^{16}$, kiedy to pobici przez nich mieli błagać cesarza Walensa o schronienie, a ten okazał im litość i współczucie, wydzielając im pod zasiedlenie obszary na terenie Tracji ${ }^{17}$.

Sozomen wyraźnie zmodyfikował relację Sokratesa. Swój przekaz na temat ówczesnych zawirowań zaczął od zmagań Gotów i ich porażki w walce z Hunami. W jej wyniku mieli wysłać poselstwo - z biskupem Wulfilą na czele - zabiegające o zgodę na osiedlenie się na terenie cesarstwa, dzięki któremu umożliwiono im zamieszkanie w Tracji. Dopiero później Sozomen opisał konflikt między Atanarykiem i Fritigernem, wskazując podobnie do Sokratesa, że ten ostatni, manifestując swą lojalność i przyjaźń do Walensa, „złączył się z cesarzem więzami wspólnej z nim wiary”"18, do czego namówił też podlegających jego władzy Gotów. Sozomen, dostrzegając jednak wspomniany brak spójności przekazu Sokratesa, zaznaczył od razu, że nie była to jedyna przyczyna przejścia Gotów na arianizm. Drugiej upatrywał w postawie biskupa Wulfili, który początkowo zgadzał się z nauką Kościoła powszechnego. Wziął co prawda udział razem z grupą Eudoksjusza i Akacjusza w synodzie konstantynopolitańskim za

13 Socrates, IV, 33.

${ }^{14}$ Ibidem, II, 41, 23.

${ }^{15}$ Ibidem, II, 41, 23.

${ }^{16}$ Ibidem, IV, 34. Migrację tę podjęli Wizygoci. Por. na ten temat Ammianus Marcellinus, XXXI, 3, 1-3, t. 6, s. 105; Eu na pios, fr. 42, s. 84-86; Zo si mo s, IV, 20, 3-5. Na temat relacji Gotów z Hunami w tym czasie zob. P. He ather, Goths and Huns [w:] The Cambridge Ancient History, vol. 13: The Late Empire, A.D. 337-425, eds. A. Camero n, P. Garn se y, Cambridge 1998, s. 487-515.

17 Socrates, 34, 2-3; tłum. S. Kazikowski, Warszawa 1986, s. 384. Walens osiedlił Gotów jesienią 376 r. w diecezji trackiej na obszarze między Bałkanem a Rodopami. Bardzo krytycznie wspomnianą decyzję cesarską oceniał Ammianus Marcellinus (XXXI 4, 4-9), wiążąc ją z zagładą rzymskiego świata (XXXI 4, 6). Jeśli wierzyć Eunapiuszowi (fr. 42), w granicach cesarstwa szukało schronienia 200 tys. wojowników gockich, co trzeba by pomnożyć kilkukrotnie, żeby otrzymać całowitą liczbę uciekinierów. Jak ujął to Ammianus Marcellinus (XXXI, 4, 9; tłum. I. Lewandowski, t. 2, Warszawa 2002, s. 229): „gromady zbrojnych barbarzyńców przykryły wszystko dookoła niczym popioły z Etny".

${ }^{18}$ Sozomenus, VI, 37, 7; thum. S. Kazikowski, Warszawa 1989, s. 442. 
panowania cesarza Konstancjusza, ale uczynił to z braku rozeznania ${ }^{19}$. Kiedy przybył do cesarza Walensa ze wspomnianym poselstwem, zdecydował się przejść na arianizm. Sozomen nie potrafił wskazać przyczyny owej decyzji, przypuszczał więc, że być może przekonano go do arianizmu lub opowiedział się za nim z przyczyn koniunkturalnych, chcąc, by cesarz pozytywnie przychylił się do prośby reprezentowanych przez biskupa Gotów. Sozomen podkreślał, że ci mieli do Wulfili całkowite zaufanie jako do tego, który wprowadzał ich w arkany wiary chrześcijańskiej, który nie tylko wymyślił alfabet gocki, ale też przełożył Pismo Święte na ich język ojczysty i który stawał w obronie wiary, narażając się na wiele niebezpieczeństw ${ }^{20}$. Atanaryk, przegrany we wspomnianej wojnie domowej, miał być oburzony na Wulfilę za to, że pod jego wpływem wielu Gotów postanowiło porzucić pogaństwo, toteż w odwecie miał zarządzić prześladowanie konwertytów, doprowadzając wielu z nich do śmierci ${ }^{21}$.

Filostorgiusz w zachowanych fragmentach nazywa Gotów Scytami i wspomina o ich ucieczce przed Hunami na terytorium Rzymian, gdzie przybyli jako przyjaciele ${ }^{22}$. Początkowo, wedle niego, zachowywali się wobec Rzymian przyjaźnie, ale wkrótce rozpoczęli rabunek i niewypowiedzianą wojnę ${ }^{23}$. Według Teodoreta z Cyru już na początku panowania Walensa Goci mieli przekroczyć Dunaj i zniszczyć Trację. Zanim cesarz zebrał wojsko i wyruszył przeciwko wrogom, postanowił przyjąć chrzest, by zapewnić sobie łaskę Bożą. Zwiedziony jednak przez żonę przyjął chrzest $\mathrm{z}$ rąk arianina, Eudoksjusza, który odebrał wówczas od niego przysięgę, że będzie zwalczał oponentów bezbożnej nauki ${ }^{24}$. Tenże Eudoksjusz miał namówić cesarza do wywarcia presji na Gotów, którzy po przekroczeniu Dunaju prowadzili z Rzymianami pokojowe negocjacje, aby przyjęli wyznanie ariańskie. Ci jednak, od dawna będąc chrześcijanami, nie chcieli porzucać wiary ojców. Eudoksjusz skupił się więc na bardzo wpływowym wśród Gotów biskupie Wulfili, którego przekonał słownie i przy pomocy pieniędzy, argumentując, że podział Kościoła był wynikiem ambicji, a nie różnic na gruncie dogmatycznym. W ten sposób Goci nawiązali wspólnotę z Eudoksjuszem, ale z wiary oddziedziczonej po ojcach nie zrezygnowali całkowicie - choć bowiem uznawali Ojca za większego od Syna, tego ostatniego nie nazywali stworzeniem ${ }^{25}$.

W relacji Sokratesa, jak już wspomniano, Goci, którzy ocaleli z konfrontacji z Hunami, stali się uchodźcami na terytorium cesarstwa rzymskiego. Sokrates podkreślał, że władca, zgadzając się na to, nie kierował się rozwagą, a jedynie uczuciem empatii, skoro nie myślał o konsekwencjach, jakie może w przyszłości przynieść podjęta przez niego decyzja. Wprost przeciwnie, jak ujął to Sokrates, „,był niezłomnie przekonany,

${ }^{19}$ Chodziło o synod z $360 \mathrm{r}$.

${ }^{20}$ Sozomenus, VI, 37.

${ }^{21}$ Ibidem, VI, 37; Passio Sanctae Sabae Gothi, ed. H. Deleh ay e, „Analecta Bolandiana” 1912, nr 31, s. 216-221.

${ }_{22}$ Philostorgius, Kirchengeschichte, Hg. J. Bidez, bearb. F. Winkelmann, Berlin 1981, IX, 17 [dalej: Philostorgius].

${ }^{23}$ Ibidem, IX, 17.

${ }^{24}$ Theodoretus, IV, 12.

${ }^{25}$ Ibidem, IV, 37. 
że wygrał w ten sposób wielką szansę"26. Sądził bowiem, że Goci utworzą armię groźniejszą dla wrogów niż Rzymianie, a w dodatku ,gotową w każdej chwili ruszyć na nieprzyjaciela"27. Co gorsza, władca miał z tego powodu zaniedbać „dokonywania uzupełnień garnizonów złożonych z Rzymian” i w zamian za rezygnację z powoływania rekrutów z poszczególnych osad wprowadził nowy podatek wynoszący osiemdziesiąt złotych monet za każdego niepowołanego rekruta. Wyraźnie zatem Sokrates zarzucał władcy lekkomyślność i naiwność, a Gotom niewdzięczność i prymitywizm, skoro mogąc bezpiecznie korzystać z rzymskich posiadłości, nie potrafili uszanować daru losu, „lecz podnieśli się przeciwko swym dobroczyńcom i zdewastowali tereny przylegające do Tracji”28. Nieco dalej Sokrates pisał o spustoszeniu przez Gotów samej Tracji, wskazując, że łupili oni i grabili już niemal przedmieścia Konstantynopola ${ }^{29}$, wywołując frustrację mieszkańców obawiających się o los miasta i nie tylko wznoszących w hipodromie nieprzychylne okrzyki pod adresem władcy, ale też domagających się broni, by stanąć w obronie swej stolicy.

Relacja Sozomena na ten temat jest bardzo podobna, z tą różnicą, że zwrócił on uwagę,

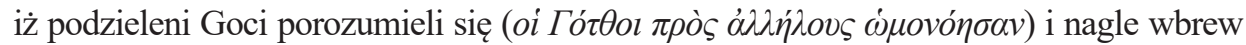
układowi przymierza zaczęli pustoszyć Trację. Wtedy dopiero Walens miał sobie uświadomić swój błąd i płonne oczekiwanie, że znajdzie w nich wiernych i oddanych cesarstwu obrońców, tak daleko idące, że zaniedbał rekrutację żołnierzy tamtejszych garnizonów ${ }^{30}$. W konsekwencji, na co zwracał uwagę Sozomen, barbarzyńcy, rozzuchwaleni bezczynnością Rzymian, szykowali się do uderzenia na mury Konstantynopola. Sozomen zatem w przeciwieństwie do Sokratesa pisał wprost o zagrożeniu miasta szturmem nieprzyjaciół. Jego mieszkańcy o bierność oskarżali cesarza Walensa, suponując nawet, że to on sam sprowadził wrogie zastępy ${ }^{31}$. Opieszałości w postępowaniu cesarza nie dostrzegł Filostorgiusz, według którego władca, gdy dowiedział się o pustoszeniu Tracji przez Gotów, opuścił Antiochię i udał się do Konstantynopola, a stamtąd na zagrożone rejony ${ }^{32}$.

\section{OFENSYWA WALENSA}

W relacji Sokratesa początkowe działania wojsk Walensa przeciwko Gotom były udane, skoro nie tylko odrzucono wrogów daleko od miasta ( $\pi \delta \rho \rho \omega \tau \tilde{\eta} \varsigma \pi \delta ́ \lambda \varepsilon \omega \varsigma)$,

26 Socrates, IV, 34, 3; thum. S. Kazikowski, Warszawa 1986, s. 385.

27 Socrates, IV, 34, 1-5; thum. S. Kazik ow ski, Warszawa 1986, s. 384-385. Goci mieli bowiem stać się częścią armii rzymskiej na stałe, a nie stanowić wsparcie jedynie w konkretnych kampaniach, do czego byli zobowiązani od czasu traktatu zawartego z nimi przez cesarza Konstatyna I; por. N. L e n ski, Failure of Empire. Valens and the Roman State in the Fourth Century A.D., Berkeley-Los Angeles-London 2002, s. 307-319.

${ }^{28}$ S o crates, IV, 35. W rzeczywistości nie bez winy byli rzymscy urzędnicy i dowódcy wojskowi, którzy swą lekkomyślnością sprowokowali Gotów. Zob. H. Wolfra m, Historia Gotów, s. 143-148.

${ }^{29}$ Socrates, IV, 38.

${ }^{30}$ Sozomenus, VI, 37, 15-17.

${ }^{31}$ Ibidem, VI, 39.

${ }^{32}$ Philostorgius, IX, 17. 
ale też ścigano ( $\dot{\varepsilon} \delta i \omega \kappa \varepsilon)$ ich aż do Adrianopola w Tracji, na pograniczu Macedonii ${ }^{33}$. Według relacji Sokratesa władca opuścił Konstantynopol 11 czerwca 378 roku $^{34}$, a bitwę pod Adrianopolem stoczył 9 sierpnia $^{35}$. Zanim jednak do niej doszło, ścigał nieprzyjaciół, co wydaje się sugerować dotkliwą porażkę Gotów. Relacja Sokratesa sprawia jednak wrażenie niespójnej, tym bardziej że w następnych zdaniach wskazywał on na klęskę poniesioną przez wojska cesarskie i śmierć samego władcy ${ }^{36}$. Cesarz, aby odrzucić ( $\dot{\omega} \theta \varepsilon \bar{\imath})$ Gotów „daleko” od Konstantynopola ${ }^{37}$, do Adrianopola, potrzebował w ujęciu historyka prawie dwóch miesięcy, od 11 czerwca do 9 sierpnia, a przecież chodziło tu o odległość wynoszącą zaledwie około $240 \mathrm{~km}$ - nieprzyjaciel znajdował się więc jeszcze na terenie będącym zapleczem Konstantynopola. Nie był to zatem pościg, a powolne wypieranie najeźdźców. W dodatku trzeba zauważyć, że Adrianopol nie leżał nawet w centralnej Tracji - bardziej w jej części południowo-wschodniej, a na pewno nie na pograniczu Macedonii, jak sugerował to Sokrates, skoro od jej granic dzieliło go również dwieście kilkadziesiąt kilometrów ${ }^{38}$. Sugestie historyka są o tyle dziwne, że jako konstantynopolitańczyk powinien dobrze orientować się w położeniu miast otaczających stolicę. Dalsza relacja Sokratesa na temat bitwy pod Adrianopolem i śmierci cesarza w niejasnych okolicznościach wyraźnie dowodzi kompletnego fiaska podejmowanych wcześniej przez władcę działań ofensywnych. Historyk wskazywał bowiem, że barbarzyńcy „podeszli pod same mury Konstantynopola i pustoszyli leżące wokół niego tereny podmiejskie"39.

Wydaje się, że Sozomen był świadomy błędu popełnionego przez Sokratesa, zmodyfikował bowiem jego przekaz. Jak relacjonuje, kiedy wojska rzymskie zaata-

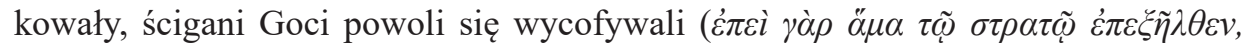

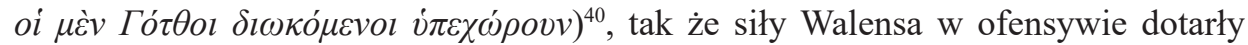
do Adrianopola. W opisie Sozomena ofensywa Rzymian nie miała więc rozmachu, jaki przypisywał jej Sokrates. Historyk pominął też kwestię czasu, który upłynął od wyjścia władcy z miasta do bitwy pod Adrianopolem. Zwrócił uwagę, że Goci z wolna ustępowali ścigani przez Rzymian ${ }^{41}$. Jakkolwiek więc wojska Walensa napierały, o rozsypce sił nieprzyjacielskich nie było mowy, nastąpił raczej zorganizowany odwrót. Sozomen nie określił w żaden sposób położenia Adrianopola. Zrezygnował więc z jego lokowania na pograniczu z Macedonią, jak czynił to Sokrates, jednak podana przez niego informacja, że cesarz przeszedł przez Trację, nim dotarł do wspomnianego miasta, może sugerować, że leży ono gdzieś na jej pograniczu.

${ }^{33}$ Socrates, IV, 38, 6.

${ }^{34}$ Ibidem, HE IV, 38, $2-3$.

${ }^{35}$ Ibidem, IV, 38, 7.

${ }^{36}$ Ibidem, IV 38, 7-11. Na temat klęski pod Adrianopolem zob. N. Le n s k i, Initium ..., s. 129-168.

37 Socrates, IV, 38, 6; thum. S. Kazikowski, Warszawa 1986, s. 389.

${ }^{38}$ Ammianus Marcellinus (XIV 11, 15) nazywa Adrianopol urbs Haemimontana, a przymiotnik ten występuje jedynie w jego dziele. Zob. J. den Boeft, J.W. Drijvers, D. den Hengst, H.C. Teitler, Philological and Historical Commentary on Ammianus Marcellinus XXVII, Leiden-Boston 2009 , s. 86.

${ }^{39}$ Socrates 1, 1; thum. S. Kazikowski, Warszawa 1986, s. 394.

${ }^{40}$ Sozomenus, VI, 40, 2.

${ }^{41}$ Ibidem, VI, 40, 2. 


\section{ŚMIERĆ WALENSA}

Relacja Rufina na temat śmierci Walensa jest niezwykle oszczędna. Historyk skonstatował jedynie, że ten, wyruszywszy przeciw wrogom, schronił się ze strachu przed bitwą w pewnej posiadłości, gdzie zapłacił za swoją bezbożność spaleniem na popió ${ }^{42}$. Przekaz Sokratesa również zaskakuje swą zwięzłością, na temat losu samego władcy napisał bowiem jedynie: „tam w bitwie z barbarzyńcami zginął dnia dziewiątego sierpnia" ${ }^{\prime 3}$. Nie podał przy tym żadnych informacji odnoszących się do przyczyn tej nieoczekiwanej klęski wobec wcześniejszego powodzenia ofensywy prowadzonej przeciw Gotom. Swoją uwagę skoncentrował na domniemanych losach władcy, podając przy tym dwie relacje na temat jego śmierci. „Jedni mówią”, jak pisał, że cesarz zginął w ogniu w osadzie spalonej przez barbarzyńców, szukając w niej schronienia; „drudzy powiadają”, wywodził historyk, że władca w stroju zwykłego żołnierza, nierozpoznany, zginął z innymi piechurami w walce $\mathrm{z}$ barbarzyńca$\mathrm{mi}^{44}$. Według Filostorgiusza Walens przypadkowo spłonął w budynku, w którym się schroni ${ }^{45}$.

Sozomen i tym razem nieco inaczej przedstawił wydarzenia, podał bowiem przyczynę klęski Walensa i zarysował bardzo ogólnie przebieg bitwy. Wskazywał, że cesarz polecił zaatakować nieprzyjaciół, gdy jego wojska znalazły się w niewielkiej odległości od nich. Ich obóz był rozłożony w bezpiecznym miejscu ( $\dot{\varepsilon} v \alpha \dot{\alpha} \sigma \varphi \alpha \lambda \varepsilon \tilde{\varepsilon} \chi \omega \rho i ́ \omega$ $\sigma \tau \rho \alpha \tau o \pi \varepsilon \delta \varepsilon v o \mu \varepsilon ́ v o l \varsigma)$, barbarzyńcom sprzyjała więc nie tylko sama lokalizacja ich wojsk, ale prawdopodobnie także jakiegoś rodzaju obwarowanie, skoro armia Walensa natknęła się na gocki obóz wojskowy ( $\sigma \tau \alpha \tau$ i jaciołom bezpieczeństwo ( $\sigma \varphi \varphi \dot{\lambda} \lambda \varepsilon l \alpha)$. Przynajmniej tak to sobie wyobrażał Sozomen. Historyk podkreślał następnie lekkomyślność cesarza, który jego zdaniem „uderzył szybciej, niż było potrzeba, bez uprzedniego ustalenia, jak i gdzie ustawić należy wojsko" ${ }^{46}$. Sozomen nie dowodził więc przewagi liczebnej wroga, ale wskazywał na nieumiejętne dowodzenie po stronie Rzymian, skoro ich wódz działał w sposób pochopny oraz nieprzemyślany i nie potrafił należycie ustawić do bitwy swej armii. Widać nadzieję wiązał ze znaczącą przewagą swoich wojsk i elementem zaskoczenia

${ }^{42}$ Rufinus, XI, 13.

${ }_{43}$ Socrates, IV, 38, 7; thum. S. Kazikowski, Warszawa 1986, s. 389.

${ }_{44}$ Ibidem, IV, 38, 7-11. Podobnie opisywał jego śmierć A mmianus Marcellinus (XXXI, 13, 12-17), wedle którego cesarz padł przeszyty strzałą wśród zwykłych żołnierzy bądź też spłonął w wieśniaczej chacie. Zob. też Hi eronymus, Chronicon, a. 378, ed. R. Helm, Berlin 1956; Ru finus, II, 13; Philostorgius, IX 17; Sozomenus, VI, 40, 2-5; Theodoretus, IV 37, 2; Dla A mbrożego z Medi i la nu (De fide ad Gratianum Augustum, II, 141-142 [w:] PL, t. 16) śmierć Walensa była karą za prześladowanie ortodoksów. Natomiast Lib a ni us z (Orationes, 24, 4, wyd. R. F o er ster e, vol. 1, Lipsiae 1903) dowodził, że Walens zginął, walcząc na koniu. Noel Le nski (Initium..., s. 152) zwrócił uwagę, że niemal natychmiast po klęsce pod Adrianopolem w Konstantynopolu powiązano śmierć cesarza z jego arianizmem i prześladowaniami zwolenników nicejskiego credo, ale także z prześladowaniem pogan (s. 163).

${ }^{45}$ Philostorgius, IX, 17.

46 Sozomenus, VI, 40. 
wynikającym z szybkości działania. Przeliczył się jednak - najpierw została rozbita jego konnica, a następnie wojska piesze rzuciły się do odwrotu i w końcu sam władca musiał podjąć ucieczkę ścigany przez nieprzyjaciół. Przedstawiając los Walensa, Sozomen ograniczył się jedynie do wersji, wedle której cesarz spłonął wraz z grupą towarzyszy, kiedy próbował znaleźć schronienie w jakiejś oficynie, otoczonej wkrótce i podpalonej przez Gotów. Historyk zrezygnował więc z drugiej wersji przedstawionej przez Sokratesa, zgodnie z którą władca zginął śmiercią prostego żołnierza w walce wręcz podjętej z nieprzyjaciółmi. Niewątpliwie była ona dla Walensa bardziej chwalebna i prawdopodobnie dlatego Sozomen ją pominął. Widać władca heretyk, przelewający krew chrześcijan ortodoksów, musiał umrzeć, w przekonaniu historyka, śmiercią niegodną cesarza. Znamienne są słowa Sozomena otwierające następną księgę: „Walensowi zatem tak przyszło umrzeć” (Oủó $\lambda \varepsilon v \tau \iota \mu$ ㅊv oũv $\tilde{\omega} \delta \varepsilon$

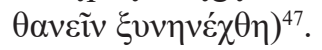

Teodoret, opisując prześladowania ortodoksów przez arian za rządów Walensa, konstatował: „w tym czasie Goci plądrowali Trację i oblegali miasta”48. Co więcej, dowodził, że to sam Bóg, przyjaciel ludzi, zachęcił do wojny Gotów i wciągnął do niej Walensa, „który potrafił walczyć jedynie z prawdziwą wiarą"49. Przekonany o tym, że Bóg napuścił na Walensa barbarzyńców, miał być także niejaki mnich Izaak, cytowany przez Teodoreta ${ }^{50}$. Zaniepokojony rozwojem sytuacji Walens miał zabiegać u swego brata Walentyniana o przysłanie wojskowej pomocy ${ }^{51}$. Ten jednak odmówił, wskazując, że nie godzi się pomagać komuś, kto walczy z Bogiem, a wprost przeciwnie - lepiej byłoby położyć temu kres ${ }^{52}$.

Teodoret, przypisując Walensowi strach przed konfrontacją z Gotami, zarzucał mu zbyt długi pobyt w Konstantynopolu. W tym czasie miał co prawda wysłać przeciwko barbarzyńcom armię pod dowództwem Trajana ${ }^{53}$, ale poniosła ona porażkę, za którą władca miał obwiniać wspomnianego dowódcę. Ten zaś odpierał zarzuty, dowodząc, że to nie on został pokonany, lecz sam cesarz, stając przeciwko Bogu. Podjąwszy z Bogiem walkę, sprawił, że Ten stronie barbarzyńców, tak więc to sam władca pozwolił im pozyskać Jego przychylność. Konstatować miał Trajan, a za nim Teodoret: „zwycięstwo podąża za Bogiem" ${ }^{54}$. Jeszcze dalej wedle Teodoreta miał posunąc się pewien mnich Izaak, o którym wspominał także Sozomen ${ }^{55}$. Jak wskazywał biskup Cyru, mnich ów nie tylko dowodził, że Walens walczy przeciwko Bogu i dlatego nie ma od Niego pomocy, ale wręcz, że to sam Bóg napuścił na

47 Ibidem, VII, $1,1$.

${ }^{48}$ Theodoretus, IV, 15.

${ }^{49}$ Ibidem, IV, 31.

50 Ibidem, IV, 34.

${ }^{51}$ Oczywiście Teodoret myli się w tym miejscu, gdyż Walentynian I nie żył już od roku 375. Adresatem listu był Gracjan, bratanek Walensa. Zob. A mmianus Marcelinus, XXXI, 10.

52 Ibidem, IV, 32 (31).

${ }^{53}$ Trajan był komesem Armenii. Według A mmiana Marcellina (XXXI, 7, 1) był on dowódcą wojskowym o dużych aspiracjach, ale mało walecznym. W wojnie z Gotami dowodził piechotą.

${ }^{54}$ Ammianus Marcelinus, IV 33.

${ }^{55}$ Sozomenus, VI, 40. Zob też: Zonaras, Ioannis Zonarae Epitome historiarum, XIII, 16, ed. T. Büttner-Wobst, Bonnae 1897. 
niego barbarzyńców. Wołał Izaak do cesarza: „Przestań walczyć z Bogiem, to i On przestanie walczyć z tobą. Daj owcom najlepszych pasterzy, a bez trudu odniesiesz zwycięstwo" 56 .

Ostatecznie, na co zwrócił uwagę Teodoret, Walens nie posłuchał dobrych rad i nie zmienił swej polityki religijnej. Wyruszył w końcu na wojnę przeciw Gotom, ale do bezpośredniej walki wysłał innych. Sam zaś zatrzymał się w jednej z wsi, gdzie miał, wedle Teodoreta, czekać na wiadomość o zwycięstwie. Wysłani żołnierze ponieśli jednak klęskę i zostali zmuszeni do ucieczki, w czasie której ścigano ich i zabijano. W końcu pościg dotarł do wioski, gdzie oczekiwał Walens, na próżno szukający schronienia. Teodoret konstatował, że wróg prawdziwej wiary zginął w ogniu podłożonym przez barbarzyńców i w ten sposób jeszcze w tym życiu poniósł karę za popełnione przez siebie zbrodnie ${ }^{57}$.

\section{IMPERIUM ROMANUM PO KLĘSCE POD ADRIANOPOLEM}

Sytuacja cesarstwa po śmierci Walensa przedstawiała się według zgodnej opinii historyków kościelnych dramatycznie. Rufin konstatował, że wspomniana klęska była początkiem złych czasów dla imperium rzymskiego ${ }^{58}$. Filostorgiusz podkreślał, że w jej konsekwencji barbarzyńcy, którym przewodził Fritigern, swobodnie łupili Trację ${ }^{59}$. Sokrates zwracał uwagę, że pojawienie się barbarzyńców pod murami Konstantynopola i pustoszenie przez nich tamtejszych terenów podmiejskich wywołały spontaniczną reakcję samych mieszkańców, którzy, „chwytając co kto miał pod

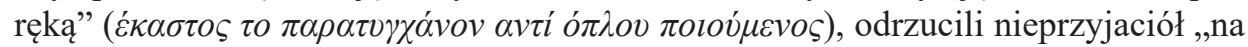

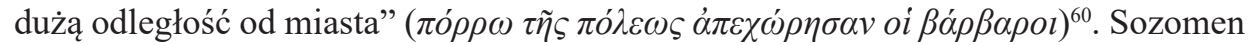
w dalszym toku swej relacji wskazywał na bardzo groźne dla państwa konsekwen-

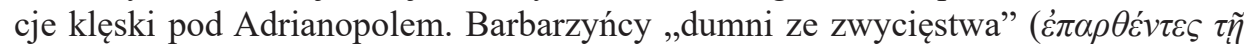
víkn $)^{61}$, jak pisał Teodoret, nabrawszy odwagi po odniesionym zwycięstwie ${ }^{62}$, nie tylko pustoszyli całą Trację, ale najechali też podmiejskie okolice Konstantynopola ${ }^{63}$. Kontrofensywa podjęta przez mieszkańców opłacanych przez cesarzową (według Sozomena ze skarbca państwowego, a nie - jak twierdził Sokrates - z cesarskiego)

${ }^{56}$ Ibidem, IV, 34. Na temat owego mnicha i przypisywanego mu incydentu zob. N. Le n ski, Valens and the Monks: Cudgeling and Conscription as a Means of Social Control, „Dumbarton Oaks Papers” 2004 , no. 58, s. $107-113$.

57 Sozomenus, IV, 36.

${ }^{58}$ Rufinus, XI, 13.

${ }^{59}$ Philostorgius, IX, 17-19.

${ }^{60}$ Socrates, V, 1.

${ }^{61}$ Sozomenus, VII, 1, 1; thum. S. Kazikowski, Warszawa 1989, s. 452.

${ }_{62}$ Theodoretus, V, 5.

${ }^{63}$ Sozomenus, VII, $1,1$. 
i wspartych przez Saracenów przysłanych przez Mawię odrzuciła nieprzyjaciół „daleko od miasta" ( $\pi \dot{\rho} \rho \rho \omega \tau \tilde{\eta} \varsigma \pi \delta ́ \lambda \varepsilon \omega \varsigma)^{64}$.

Jak wskazywał Sokrates, także cesarz Gracjan świadomy był poważnego zagrożenia dla panowania rzymskiego i przewagi, jaką zyskiwały siły barbarzyńskie, toteż dobrał sobie za współwładcę na Wschodzie doświadczonego dowódcę, jakim był Teodozjusz I (379-395) ${ }^{65}$, z którym ostatecznie barbarzyńców pokonał ${ }^{66}$. Jak wskazywał Sozomen, cesarz Gracjan, zatroskany o los Illyricum i Tracji nękanych przez barbarzyńców znad Dunaju, wziął sobie w Sirmium za wspólnika władzy Teodozjusza $^{67}$, który zwyciężając jednych barbarzyńców na polu walki, a z drugimi zawierając przymierze, opanował groźną sytuację ${ }^{68}$. Podobnego zdania był Filostorgiusz, wedle którego Teodozjusz w okolicach Sirmium doprowadził do klęski barbarzyńców ${ }^{69}$. W przekonaniu Teodoreta Teodozjusz ,zabezpieczony przez wiarę” ( $\tau \tilde{\eta} \pi i \sigma \tau \varepsilon l$ $\varphi \rho \alpha \xi \dot{\alpha} \mu \varepsilon v o \varsigma)$ stoczył bitwę, w której większość barbarzyńców zginęła czy to z rąk Rzymian, czy też z rąk współplemieńców w trakcie chaotycznej ucieczki. Zwycięstwo zaś Teodozjusza było tak druzgocące, że Gracjanowi wydawało się niewiarygodne aż do chwili, kiedy potwierdzili je specjalni wysłannicy. Przekonany o słuszności decyzji o powierzeniu Teodozjuszowi naczelnego dowództwa, wyniósł go na cesarski tron, powierzywszy mu część cesarstwa znajdującą się wcześniej we władaniu Walensa ${ }^{70}$.

\section{PODSUMOWANIE}

Po przeanalizowaniu relacji autorów Historii kościelnych na temat kryzysu wywołanego migracją Gotów w drugiej połowie IV wieku rzuca się przede wszystkim w oczy różny stopień szczegółowości ich przekazu. Wydaje się, że odległość geograficzna ośrodków, z którymi byli związani poszczególni autorzy, nie miała dużego znaczenia. W przypadku Rufina z Akwilei zdawkowość informacji dotyczących Gotów była niewątpliwie spowodowana ogólną zwięzłością jego dzieła. Jeśli chodzi zaś o Filostorgiusza, mogła wynikać z fragmentarycznego zachowania jego Historii. Ogólny charakter przekazu Teodoreta z Cyru wynikał zaś z jego teologicznego podtekstu, toteż skupiał się on na podstawowych faktach dotyczących pustoszenia przez Gotów Tracji, przyjęciu przez nich arianizmu, a w końcu na reakcji cesarza Walensa

${ }^{64}$ Ibidem, VII, 1, 1-2; thum. S. Kazikow ski, Warszawa 1989, s. 452.

${ }^{65}$ Socrates, V, 2.

${ }^{66}$ Ibidem, V, 6.

${ }^{67}$ Sozomenus, VII, $2,1$.

${ }^{68}$ Ibidem, VII, 4, 2.

${ }^{69}$ Philostorgius, IX, 17-19. Filostorgiusz jako jedyny wspomina o zwycięstwie Teodozjusza pod Sirmium. Nie można wykluczyć, że Focjusz, który streszczał jego dzieło, mógł pomylić miejsce wyboru Teodozjusza z miejscem bitwy. Zob. P.R. A midon, Philostorgius: Church History, LeidenBoston 2007, 133, n. 40.

${ }^{70}$ Theodoretus, V, 5-6. 
na zagrożenie z ich strony. Teodoret nie wspomniał o naporze Hunów jako przyczynie przekroczenia przez Gotów Dunaju, upatrywał jej natomiast w woli samego Boga, który miał wedle niego zachęcić Gotów do wojny z Rzymianami. Podobnie klęskę i okrutną śmierć Walensa traktował jako karę Bożą za prześladowanie ortodoksyjnych chrześcijan. Natomiast Teodozjusz pokonał barbarzyńców, wedle Teodoreta, dzięki swej wierze i pobożności. Najwięcej miejsca w swych Historiach kościelnych kryzysowi gockiemu poświęcili Sokrates z Konstantynopola i Sozomen, przy czym wyraźnie drugi z nich korygował przekaz pierwszego, poprawiając błędy, ale też zaznaczając odmienne poglądy. $Z$ ich relacji dowiadujemy się więc o rzeczywistych przyczynach osiedlenia się Gotów na rzymskim terytorium, o wojnie domowej między Atanarykiem a Fritigernem czy o lekkomyślności Walensa jako faktycznej przyczynie, obok jego bezbożności, poniesionej przez niego klęski. Ponadto wydaje się, że Sokrates odnosił się do nich z większą pogardą niż pozostali, unikając ich nazwy własnej - Goci, z upodobaniem natomiast pisząc o nich jako o barbarzyńcach ${ }^{71}$. Wszyscy natomiast z omawianych autorów zdawali sobie sprawę z dramatycznej sytuacji, w jakiej znalazło się cesarstwo po klęsce pod Adrianopolem.

\section{BIBLIOGRAFIA}

\section{Źródła drukowane}

A mbrosius, De fide ad Gratianum Augustum [w:] PL, t. 16, kol. 527-698.

A mbrosiu s, Expositio Evangelii secundum Lucam, ed. M. Adri a en, Turnhout 1957.

Ammianus Marcellinus, Rerum gestarum libri qui supersunt, ed. C.V. Clark, t. I-II, Berlin 1910-1915.

Eunapios z Sardes, Zapiski historyczne. Istorika Upomnemata, wyd. i thum. A. Pająkowska-Bouallegui, Gdańsk 2013.

Hieronymus, Chronicon, ed. R. Helm, Berlin 1956.

Philostorgius, Kirchengeschichte, Hg. J. Bidez, bearb. F. Winkelmann, Berlin 1981.

Rufinus Aquileiensis, Historia ecclesiastica, ed. E. Schwartz, T. Mommsen, F. Winkelmann, Berlin 1999.

Libanios, Orationes - Libanii opera, ed. R. Foerstere, vol. 1-4, Lipsiae 1903-1908. Passio Sanctae Sabae Gothi, ed. H. Delehaye, „Analecta Bolandiana” 1912, no. 31, s. 216-221.

Socrates, Kirchengeschichte [Historia ecclesiastica], ed. G.Ch. Hansen, Berlin 1995. Sokrates Scholastyk, Historia Kościoła, tłum. S. Kazikowski, wstęp E. Wipszycka, kom. A. Ziółkow ski, Warszawa 1986.

Sozomenus, Kirchengeschichte [Historia ecclesiastica], ed. J. Bidez, G.Ch. Hansen, Berlin 1995.

Theodoretus, Kirchengeschichte [Historia ecclesiastica], ed. L. Parmentier, G.Ch. Han s en, Berlin-New York 2009.

${ }^{71}$ Właściwie w dwóch miejscach, kiedy historyk pisał o zwycięstwach nad nimi cesarza Konstantyna (S o c r a te s, I, 18,4) i o targającej nimi wojnie domowej, przyjęciu przez nich chrześcijaństwa i działalności ich biskupa Wulfili (ibidem, IV, 33). 
Zo naras, Ioannis Zonarae Epitome historiarum, XIII 16, ed. T. B üttner-Wobst, Bonnae 1897.

Zosimos, Historia Nova, ed. F. P a s choud, t. 2, Paris 1979.

\section{Opracowania}

A mi d on P.R., Philostorgius: Church History, Leiden-Boston 2007.

Barnes T.D., The Collapse of the Homoeans in the East, „Studia Patristica” 1997, no. 29, s. 3-16.

Berndt G.M., Aktionsradien gotischer Kriegergruppen, „Frühmittelalterliche Studien” 2014, Bd. 47, H. 1, s. 7-52.

B oeft J. den, Drijvers J.W., Heng st D. den, Teitler H.C., Philological and Historical Commentary on Ammianus Marcellinus XXVII, Leiden-Boston 2009.

Burns T.S., The Battle of Adrianople: A Reconsideration, „Historia” 1973, vol. 22, no. 1, s. 336-345.

De mandt A., Geschichte der Spätantike. Das Römische Reich von Diocletian bis Justinian 282-565 n. Chr., München 2008.

Faber E., Athanarich, Alarich, Athaulf. Zum Wandel westgotischer Herrschaftskonzeptionen, „Klio” 2010, Bd. 92, H. 1, s. 157-169.

Hals all G., Barbarian Migrations and the Roman West, 376-568, Cambridge 2007.

He ath er P., Goths and Huns [w:] The Cambridge Ancient History, vol. 13: The Late Empire, A.D. 337-425, eds. A. Camero n, P. Garn s ey, Cambridge 1998, s. 487-515.

Heather P., Upadek cesarstwa rzymskiego, tłum. J. S zc zepań ski, Poznań 2006.

K a e gi W.E., Byzantium and the Decline of Rome, Princeton 1968.

K a m pers G., Geschichte der Westgoten, Paderborn 2008.

Lenski N., Failure of Empire: Valens and the Roman State in the Fourth Century A.D., Berkeley-Los Angeles-London 2002.

L e n s k i N., Initium mali Romano imperio: Contemporary Reactions to the Battle of Adrianople, „Transactions of the American Philological Association” 1997, no. 127, s. 129-168.

Le nski N., Valens and the Monks: Cudgeling and Conscription as a Means of Social Control, „Dumbarton Oaks Papers” 2004, no. 58, s. 93-117.

Me i e r M., Geschichte der Völkerwanderung: Europa, Asien und Afrika vom 3. bis zum 8. Jahrhundert n. Chr., München 2020.

Pawlak M.N., Cesarstwo rzymskie od Walentyniana I do Teodozjusza I (363-395) [w:] Świat rzymski w IV wieku, red. P. Filipczak, R. Kosiński, Kraków 2015.

Rutowski B., Bitwa pod Adrianopolem (9 VIII 378 r.) i jej nastęstwa, „Meander” 1978, t. 33, nr 11-12, s. 525-539.

S a la mon M., Rozpad i upadek cesarstwa rzymskiego. Społeczeństwo wobec nowych struktur politycznych [w:] Starożytny Rzym we współczesnych badaniach. Państwo - społeczeństwo - gospodarka. Liber in memoriam Lodovici Piotrowicz, red. J. Wols ki, T. Kotula, A. Kunis z, Kraków 1994.

Wanke U., Die Gotenkriege des Valens. Studien zu Topographie und Chronologie im unteren Donauraum von 366 bis 378 n. Chr., Europäische Hochschulschriften, Reihe III Geschichte und ihre Hilfswissenschaften, Bd. 412, Frankfurt am Main 1990.

Wilczyńs ki M., Germanie w stużbie zachodniorzymskiej wV w. n.e., Oświęcim 2018.

Wilczyńs ki M., Wizygoci w rejonie Bałkanów w teorii i praktyce politycznej dworów późnego Cesarstwa Rzymskiego, „Vox Patrum” 2016, t. 66, nr 26, s. 302-303.

Will i a m s S., Friell G., Theodosius the Empire at Bay, London 2005, s. 152-156.

Wolfram H., Historia Gotów, thum. R. Darda-S ta ab, I. Dę bek, K. Berger, Warszawa 2003. 